\title{
DISSEMINATION OF THE GENEVA CONVENTIONS
}

$A$ resolution of the $X X I I n d$ International Conference of the Red Cross asked the ICRC to centralize information on the dissemination of the Geneva Conventions in the world with a view to regularly imparting such information to National Societies and Governments. The International Review is therefore publishing information supplied by National Societies on the subject.

\section{GERMAN DEMOCRATIC REPUBLIC}

The German Red Cross of the German Democratic Republic has just published an excellent 24-page summary of the four Geneva Conventions of 1949.

The National Society informs the ICRC that the booklet has been distributed to its various local chapters. With its clear layout and practical format, the summary should reach a wide public.

\section{POLAND}

The Polish Red Cross recently produced a brochure of some forty pages to convey to the general public the importance of international humanitarian law in the present-day world and to disseminate the Red Cross principles and the 1949 Geneva Conventions as widely as possible. ${ }^{1}$ It contains the following chapters: 1 . International humani-

${ }^{1}$ The brochure, published in Warsaw and entitled Miedzynarodowe Prawo Humanitarne, is by Mr. Tadeusz Mallik. 
tarian law; 2. General characterictics of the Geneva Conventions of 12 August 1949 for the protection of war victims; 3. First Geneva Convention; 4. Second Geneva Convention; 5. Third Geneva Convention; 6. Fourth Geneva Convention; 7. The red cross emblem, its importance and the protection it affords; 8. War victims information service; 9. Repression of abuses and breaches; 10. Trends in the development of international humanitarian law.

\section{SPAIN}

The Spanish Red Cross holds courses on the Red Cross and the Geneva Conventions for students at the teacher-training university, to acquaint them of the movement's aims, structure and activities, so that they may initiate schoolchildren at an early age in the Red Cross spirit, teach them what it means, and convey an understanding of how important it is that its principles should receive practical fulfilment in the world.

Each course lasts three days and covers the following subjects: Principles and International Conventions; Information on the Red Cross in general; Information on the Spanish Red Cross; Methods for imparting such knowledge in schools; How teachers can apply themselves to the task with their pupils and how they can act through colleagues.

Film shows are held, and the course ends with a series of practical demonstrations carried out by relief units in the province concerned. Further, a member of the National Directorate conducts a meeting at which some subject is discussed, each participant being supplied with the relevant documents.

At the first meeting, small groups (of six to ten) are formed which are, in turn, joined by representatives of provincial and national Red Cross services. These are consulted in their own particular field, on the basis of a questionnaire issued in advance. A subsequent meeting is devoted to a critical consideration of the course, and conclusions are then drawn. At the end of the course, the National Society remains in touch with the participants.

As a rule, a first-aid course follows, and the feasibility of a future single course, according to circumstances, is being considered.

\section{THAILAND}

In primary and secondary schools there is a course of instruction on the history and principles of the Red Cross as well as on the Geneva 
Conventions and other subjects, e.g. first aid and health education. Further efforts are being made for the dissemination of Red Cross principles and international humanitarian law to be included in the normal curriculum of social education, and the Department of Physical Education is working out a plan in collaboration with the Education Technique Department of the Ministry of Education, for widespread dissemination. In the meantime, the Department of Physical Education is also stressing the principles of the Red Cross and the Geneva Conventions in the course it conducts for Red Cross Juniors. ICRC documents have proved useful in the preparation of a suitable curriculum.

The Ministry of Education, the Department of Physical Education, and the Junior Red Cross, have published a number of handbooks outlining the history of the international Red Cross and of the Thai Red Cross, and dealing with subjects such as Junior Red Cross activities. These publications are used to make the Thai Red Cross and humanitarian principles known among the young. 